\title{
PENGGUNAAN ALAT TANGKAP YANG SELEKTIF UNTUK PEMANFAATAN SUMBER DAYA IKAN PARI DI LAUT JAWA
}

\author{
Subhat Nurhakim, Agustinus Anung Widodo, dan Budi Iskandar Prisantoso \\ Peneliti pada Pusat Riset Perikanan Tangkap, Ancol-Jakarta \\ Teregistrasi I tanggal: 3 Maret 2009; Diterima setelah perbaikan tanggal: 13 Maret 2009;
} Disetujui terbit tanggal: 24 Maret 2009

\section{ABSTRAK}

\begin{abstract}
Akhir-akhir ini FAO mempunyai kepedulian yang serius akan keberadaan sumber daya ikan Elasmobranchii. Kepedulian tersebut direfleksikan dalam bentuk dikembangkannya International Plan of Action untuk konservasi dan pengelolaan ikan cucut atau hiu (shark). Hal ini bukan tidak mungkin akan dikenakan juga bagi komoditas ikan pari (rays) di masa mendatang. Dalam rangka memperoleh informasi yang akurat untuk mendukung kebijakan penangkapan perikanan ikan pari di Laut Jawa, maka telah dilakukan penelitian melalui survei di pusat-pusat pendaratan sumber daya ikan pari di daerah pantai utara tahun 2005-2006. Hasil penelitian menunjukkan bahwa alat tangkap penting pada perikanan ikan pari antara lain jaring dogol, jaring liongbun, dan pancing senggol. Sumber daya ikan pari tertangkap jaring dogol sebagai hasil tangkap sampingan (bycatch). Adapun pada jaring liongbun dan pancing senggol, sumber daya ikan pari merupakan sasaran tangkapan. Jenis ikan pari yang teridentifikasi selama penelitian paling tidak 36 jenis yang didominansi oleh Himantura gerrardi (30,07\%), Dasyatis kuhlii (18,57\%), H. bleekeri (11,58\%), Aetoplatea zonura $(6,28 \%)$, dan $H$. jenkinsii (5,36\%). Alat tangkap jaring liongbun dan pancing senggol bersifat selektif menangkap ikan pari, sedangkan jaring dogol tergolong sebagai alat tangkap yang tidak selektif terhadap ikan pari, karena $>50 \%$ hasil tangkapannya merupakan ikan pari muda. Dari hasil penelitian tersebut, jaring liongbun dan pancing senggol merupakan alat tangkap yang dapat direkomendasikan untuk dikembangkan.
\end{abstract}

KATAKUNCl: alat tangkap selektif, pemanfaatan dan pengelolaan, sumber daya ikan pari, Laut Jawa

\section{PENDAHULUAN}

Laut Jawa merupakan dangkalan benua (continental shelf) dengan kedalaman rata-rata $40 \mathrm{~m}$. Perairan Laut Jawa terutama dipengaruhi oleh siklus muson. Siklus muson yang terjadi di Laut Jawa adalah arus dari arah timur pada musim muson barat dan dan arus dari arah barat pada musim muson Tenggara (Durand \& Petit, 1997).

Perairan Laut Jawa merupakan daerah penangkapan ikan (fishing ground) yang paling luas di kawasan barat Indonesia. Sumber daya ikan di perairan Laut Jawa sudah lama dimanfaatkan, terutama oleh nelayan dari pantai utara Jawa. Salah satu sumber daya ikan yang saat ini mempunyai nilai ekonomi cukup penting adalah jenis ikan pari. Ikan ini tergolong ke dalam ikan bertulang rawan (Elasmobranchii).

Pada awalnya, ikan pari tertangkap sebagai hasil tangkapan sampingan dari alat tangkap yang sasaran utamanya udang atau ikan. Ikan pari pada awalnya mempunyai nilai ekonomis sangat rendah. Namun sejalan dengan perkembangan dan permintaan pasar yang terus naik akan komoditas ikan pari, sekitar 2-
3 tahun terakhir ikan pari menjadi buruan utama banyak nelayan di Laut Jawa. Ikan pari selain merupakan komoditas ekspor, juga banyak diminati di dalam negeri. Daging dan siripnya untuk bahan pangan (dikonsumsi langsung) dan kulitnya sebagai bahan baku industri fesyen.

Untuk memenuhi permintaan pasar akan sirip pari yang makin meningkat, banyak nalayan di pantai utara Jawa saat ini yang mengkhususkan usaha penangkapannya dengan sasaran utama ikan pari. Alat tangkap yang digunakan berupa jaring insang dan rawai yang khusus didesain untuk menangkap ikan pari. Selain itu sebagian besar nelayan tetap memperoleh tangkapan ikan pari sebagai bagian dari hasil tangkapan alat tangkap cantrang atau dogol (danish seine), trammel net atau alat tangkap lain.

Pada tahun teraknir ini, dunia international mulai mempunyai kepedulian yang serius terhadap keberadaan ikan-ikan Elasmobranchii akibat tekanan eksploitasi yang begitu intensif. Kepedulian tersebut direfleksikan ke dalam kenyataan oleh Badan Pangan dan Pertanian-PBB (FAO) yang telah mengembangkan International Plan of Action untuk konservasi dan pengelolaan ikan cucut atau hiu (shark). Hal ini bukan 
tidak mungkin akan dikenakan bagi komoditas ikan pari (rays) di masa mendatang. Jenis ikan pari dan cucut merupakan satu sub grup, yaitu Elasmobranchii yang mempunyai karakter biologi kurang lebih sama yaitu tumbuh lamban, matang seksual pada umur relatif tua, hanya menghasilkan sedikit anak (karena fekunditas rendah), dan berumur panjang (Compagno, 1999).

Selama ini pemerintah Indonesia kurang perhatian terhadap ikan pari yang menjadi perhatian dunia. Oleh karena itu, sekarang merupakan saat yang tepat untuk memulai lebih serius melakukan penelitian ikan-ikan Elasmobranchii, termasuk ikan pari. Informasi yang akurat dari hasil penelitian sangat berguna sebagai dasar kegiatan pengelolaan dan pemanfaatan yang berkelanjutan (sustainable). Selain itu, mendukung program International Plan of Action dari FAO tersebut di atas dijabarkan menjadi kebijakan nasional melalui National Plan of Action.

Tulisan ini membahas hasil penelitian tahun 2005 2006 tentang penggunaan alat tangkap selektif untuk pemanfaatan sumber daya ikan pari di Laut Jawa. Diharapkan informasi ini dapat digunakan sebagai acuan kebijakan pemanfaatan dan pengelolaan sumber daya ikan pari di Laut Jawa sekaligus sebagai bahan referensi dalam menyusun National Plan of Action perikanan ikan pari.

\section{BAHAN DAN METODE}

Penelitian ini dilakukan tahun 2005-2006, data diambil dengan cara stratified random sampling, di mana tempat pendaratan ikan dipilih berdasarkan pada kriteria banyak kapal yang mendaratkan hasil tangkapan ikan pari, frekuensi pendaratan tinggi (tiap hari ada pendaratan ikan pari). Tempat pendaratan ikan terpilih meliputi Pelabuhan Perikanan Muara Angke (DKI-Jakarta), Pelabuhan Perikanan Kejawanan (Jawa Barat), Pelabuhan Perikanan Pekalongan dan Juwana (Jawa Tengah), dan Pelabuhan Perikanan Brondong (Jawa Timur).

Data ekploitasi dan biologi ikan (komposisi jenis, ukuran, dan jenis kelamin) diperoleh dari contoh masing-masing pelabuhan perikanan yang telah ditentukan (terpilih). Contoh alat tangkap maupun ikan pari diambil secara acak.

Data teknik dan daerah penangkapan diperoleh dengan cara mengikuti operasi penangkapan dari kapal penangkap komersial yaitu kapal jaring dogol, kapal jaring liongbun, dan kapal pancing senggol. Selanjutnya dari masing-masing jenis kapal tersebut dipilih secara acak untuk diikuti kegiatan operasionalnya di laut. Pada kegitatan penelitian di laut ini, juga dilakukan pengamatan contoh hasil tangkapan ikan yang diambil secara acak. Kegiatan pengamatan ini dibantu observer, enumerator, dan teknisi.

Ikan contoh diidentifikasi berdasarkan pada referensi taksonomi ikan pari dari Tarp \& Kailola (1982) dan Compagno (1984). Masing-masing jenis dihitung dan dikompilasi berurutan untuk mengetahui dominasi jenis ikan pari yang ditangkap di Laut Jawa. Ukuran ikan pari dikatakan dengan lebar cawan atau width of disk (DW). Bagian-bagian dari ikan pari dan cara mengukurnya disajikan pada Gambar 1. Masingmasing jenis yang dominan disusun sampai diperoleh sebaran ukurannya. Penentuan jenis kelamin ikan pari didasarkan ada tidaknya klasper. Ikan pari jantan memiliki klasper pada pangkal ekor.

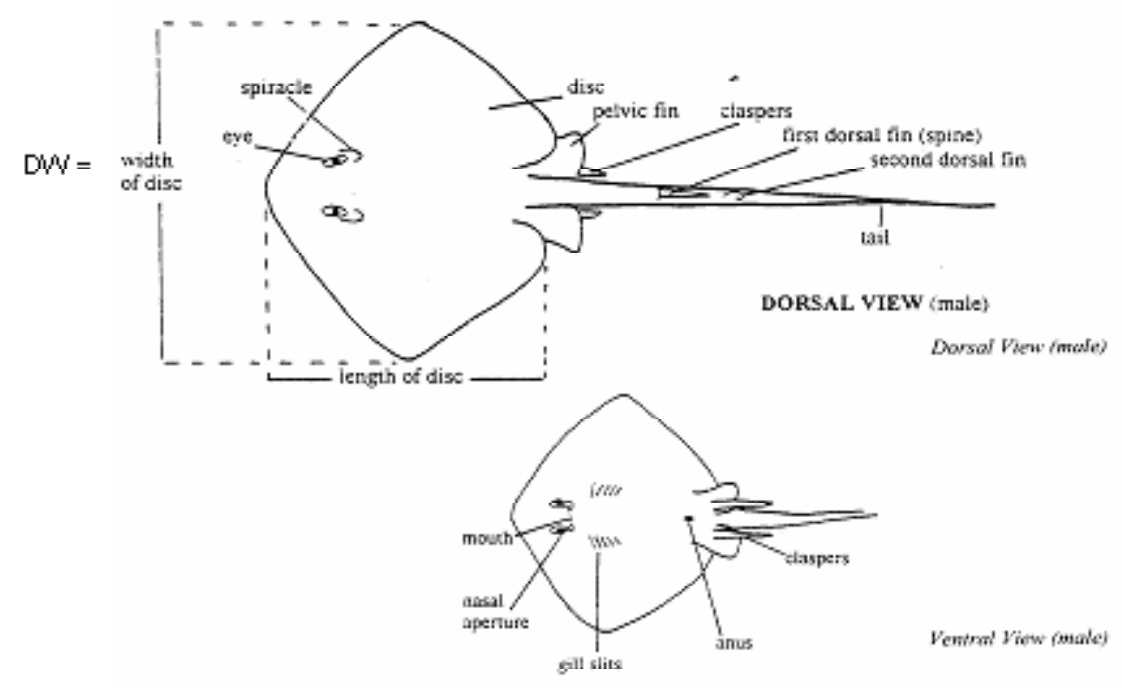

Gambar 1. Bagian-bagian dari ikan pari dan cara mengukurnya. 
Tingkat kedewasaan ikan pari jantan dilihat pada ukuran klaspernya. Sedangkan ikan pari betina didasarkan pada ada tidaknya telur pada indung telur (melalui pembedahan). Pada penelitian ini penentuan tingkat kedewasaan ikan dipilih hanya ikan pari jantan. Hal ini karena mudah dilakukan di mana ikan pari yang muda dicirikan oleh ukuran klasper (clasper) yang lebih pendek dari sirip perut ( $p e l f i c$ fin)-nya, ikan pari yang mulai dewasa dicirikan dengan ukuran panjang clasper sejajar pelfic fin dan ikan pari yang telah dewasa mempunyai clasper yang ukurannya lebih panjang dari pelfic fin-nya (Gambar 2).
Lebar cawan (disk) ikan pari yang mulai dewasa dikatakan sebagai $\mathrm{DW}_{\mathrm{m}}$ yaitu merupakan rata-rata $D_{\mathrm{m}}$ sejumlah contoh dari masing-masing 5 spesies ikan pari dominan didaratkan di tempat pengambilan contoh. Sedangkan ukuran ikan yang pertama kali tertangkap dikatakan sebagai DW merupakan $50 \%$ fraksi tertahan (ikan yang tertangkap) dari alat tangkap $\left(\mathrm{DW}_{50 \%}\right)$. Hal tersebut merupakan pengembangan dari kurva seleksi alat tangkap yang dikatakan Sparre \& Venema (1998), yaitu $L_{50 \%}=L_{c}$, atau DW ${ }_{50 \%}=D W_{c}$.

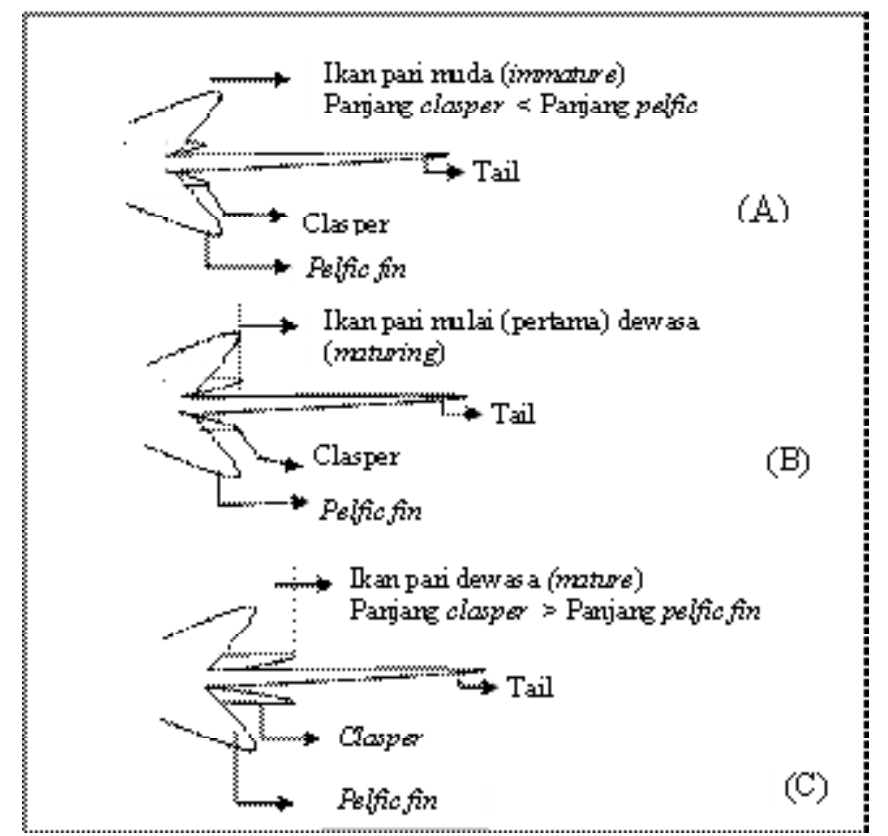

Gambar 2. Tiga tingkat kedewasaan ikan pari jantan, (A) muda, (B) pertama kali dewasa, dan (C) dewasa. Sumber: Holden, M. J. \& Rait D. F. S. (1974) in Compagno (1999)

Selektivitas alat tangkap terhadap ikan pari didekati dengan perhitungan kumulatif persentase (\%) jumlah ikan pari yang tertangkap (fraksi tertahan) oleh suatu jenis alat tangkapnya. Alat tangkap ikan dianggap tidak selektif terhadap ikan pari jika ikan pari yang tertangkap $>50 \%$ merupakan ikan muda atau lebih kecil dari $\mathrm{DW}_{\mathrm{m}}$,-nya. Dengan demikian ikanikan yang tertangkap belum berkesempatan untuk melakukan pemijahan (beranak) paling tidak 1 kali.

\section{HASIL DAN BAHASAN}

\section{Pemanfaatan Sumber Daya Ikan Pari}

\section{a. Jenis Alat Tangkap}

Selama ini ikan pari di Laut Jawa ditangkap oleh nelayan tradisional. Menurut data statistik perikanan Indonesia tercatat ada 10 jenis alat tangkap yang digunakan untuk menangkap ikan pari di Laut Jawa, yaitu dogol (danish seine), payang (lampara net), pukat pantai (beach seine), jaring insang hanyut (drift gillnet), jaring insang tetap (bottom gillnet), jaring tramel (trammel net), rawai dasar (bottom long line), pancing tangan (hand line), sero (guiding barrier), dan bubu (portable traps). Kapal yang digunakan untuk mengoperasikan alat-alat tangkap tersebut berukuran 5-15 GT dengan kekuatan mesin penggerak 12-60 HP. Jenis-jenis alat tangkap tersebut sebenarnya bukan ditujukan untuk menangkap ikan pari, melainkan udang dan ikan demersal lain. Ikan pari yang tertangkap merupakan hasil tangkapan sampingan. Untuk meningkatkan hasil tangkapan ikan pari, maka sejak 2 tahun terakhir nelayan mengembangkan teknologi alat tangkap yang khusus menangkap ikan pari yaitu jaring liongbun dan pancing senggol. 


\section{Jaring Liongbun}

Jaring liongbun tergolong alat tangkap jaring insang (gillnet) dasar. Jaring ini pada awalnya khusus ditujukan untuk menangkap ikan cucut (hiu) jenis nungnang atau liongbun (Rhynchobatus jiddensis). Namun dalam kenyataannya, pengoperasian jaring liongbun di Laut Jawa justru banyak menangkap ikan pari, terutama jenis Himatura gerrardi, H. bleekeri, dan Aetoplatea zonura yang mencapai $70 \%$ dari total hasil tangkapan. Maka selanjutnya jaring ini seolaholah khusus ditujukan untuk menangkap ikan pari. Ikan pari yang tertangkap jaring ini pada umumnya tertangkap secara terjerat (gilled) dan terpuntal (entangled). Jaring liongbun terbuat dari bahan nilon multifilamen d-21 dengan ukuran mata jaring (mesh size) $50 \mathrm{~cm}$ dan hanging ratio 0,55 . Ukuran panjang jaring (ris atas) adalah $65 \mathrm{~m}$ dan tinggi jaring $5 \mathrm{~m}$ (Gambar 3).

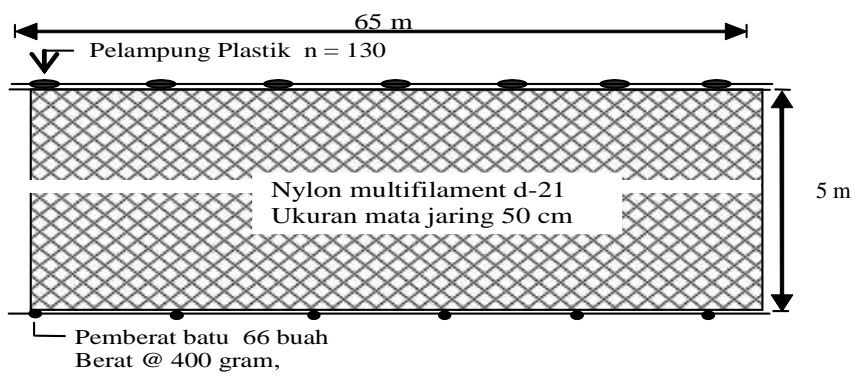

Gambar 3. Desain dan konstruksi umum jaring liongbun yang dioperasikan di Laut Jawa.

Ciri khusus dari jaring liongbun adalah ukuran mata jaringnya tergolong sangat besar $(50 \mathrm{~cm})$ dibanding ukuran mata jaring gillnet biasa digunakan untuk menangkap ikan pelagis besar yang hanya berukuran $10-12,5 \mathrm{~cm}$ atau gillnet untuk ikan demersal yang pada umumnya mempunyai ukuran mata $5-7,5 \mathrm{~cm}$. Karena konstruksinya yang khas tersebut, maka jaring liongbun cocok jika dikhususkan untuk menangkap ikan pari yang memang berukuran relatif besar. Jaring liongbun dioperasikan dengan kapal kayu bermotor ukuran 30-90 GT. Setiap kapal mengoperasikan jaring rata-rata 120 tinting (pis) atau panjang sekitar $7.800 \mathrm{~m}$. Armada penangkapan jaring liongbun berbasis di Pelabuhan Perikanan Muara Angke (DKI Jakarta) dan Pelabuhan Perikanan Kejawanan Cirebon (Jawa Barat). Satu trip penangkapan kapal jaring liongbun antara 30-90 hari dan setiap hari mengoperasikan alat sebanyak ratarata 1 kali.

\section{Pancing Senggol}

Pancing senggol adalah pancing yang didesain seperti pancing rawai dasar dengan tujuan khusus untuk menangkap ikan pari. Dalam pengoperasiannya. pancing senggol tidak menggunakan umpan. Ikan-ikan pari yang tertangkap adalah ikan pari yang sedang berenang di dasar perairan. Ikan yang sedang berenang tersebut secara kebetulan terkait oleh deretan mata pancing dari unit pancing senggol tersebut. Desain dan deskripsi umum pancing senggol yang dioperasikan di Laut Jawa adalah tali utama (main line) terbuat dari PE $\varnothing$
$3 \mathrm{~mm}$ dengan panjang total rata-rata $3.200-6.400 \mathrm{~m}$. Tali cabang (branch line) terbuat dari PE $\varnothing 2,5 \mathrm{~mm}$ dengan panjang $40 \mathrm{~cm}$. Tali cabang diikatkan pada tali utama dengan jarak 1 dengan lainnya sekitar 40 $\mathrm{cm}$. Jumlah tali cabang pada 1 unit pancing senggol pada umumnya antara 10.000-20.000 buah. Pada setiap ujung tali cabang diikatkan sebuah mata pancing. Mata pancing pada pancing senggol adalah tidak mempunyai mata kait (seperti pada mata pancing huhate). Bahan mata pancing pada umumnya adalah baja anti karat (stainless steel) ukuran $\varnothing 1,6$ $\mathrm{mm}$. Gambar 4 menyajikan desain dan konstruksi alat serta keragaannya saat diopersikan di dasar perairan.

Pancing senggol dioperasikan menggunakan kapal bermotor ukuran sekitar 6-30 GT dengan kekuatan mesin 12-120 HP. Kapal pancing senggol ukuran kapal 6-10 GT banyak ditemui di pusat pendaratan ikan Gebang (Cirebon) dan Pekalongan. Trip penangkapan armada pancing senggol di Cirebon dan Pekalongan berkisar 1-3 hari. Armada pancing senggol dengan kapal ukuran sekitar 30 GT banyak ditemui di Juwana, Pati (Jawa Tengah). Satu trip penangkapan pada umumnya mencapai 20-30 hari, 1 hari dapat mengoperasikan 2 kali. Jenis hasil tangkapan terutama Himantura gerrardi, Himantura bleekeri, dan Aetplatea zonura.

\section{Jaring Dogol}

Jaring dogol disebut juga lampara dasar (danish seine) termasuk alat tangkap ikan jenis pukat dasar (bottom seine). Alat tangkap ini ditujukan untuk 
menangkap ikan demersal termasuk ikan pari. Konstruksi umum jaring dogol adalah terdiri atas 3 bagian yaitu sayap (wing) di bagian depan, terbuat dari jaring nilon multifilament d-15 ukuran mata 12-15 $\mathrm{cm}$, badan (body) di bagian tengah terbuat dari jaring nilon multifilament d-12 ukuran mata 3,8-15 cm dan kantong (codend) di bagian belakang terbuat dari jaring nilon multifilament d-12 ukuran mata 1,7 cm (Gambar 5). Saat dioperasikan jaring dogol akan berbentuk kerucut (cone shape). Bagian pangkal depan (sayap) dibiarkan terbuka dan berfungsi sebagai mulut jaring. Sedangkan ujung dari bagian belakang (kantong) diikat sehingga ikan yang telah tertangkap tidak keluar. Dalam pengoperasiannya, jaring ini dilengkapi papan sewakan (otter board) yang berfungsi sebagai pembuka mulut ke samping. Jaring dioperasikan dengan cara ditarik dengan perahu atau kapal bermotor sepanjang dasar perairan. Ikan yang telah masuk melalui mulut akan tertampung di bagian kantong seperti halnya jaring trawl.

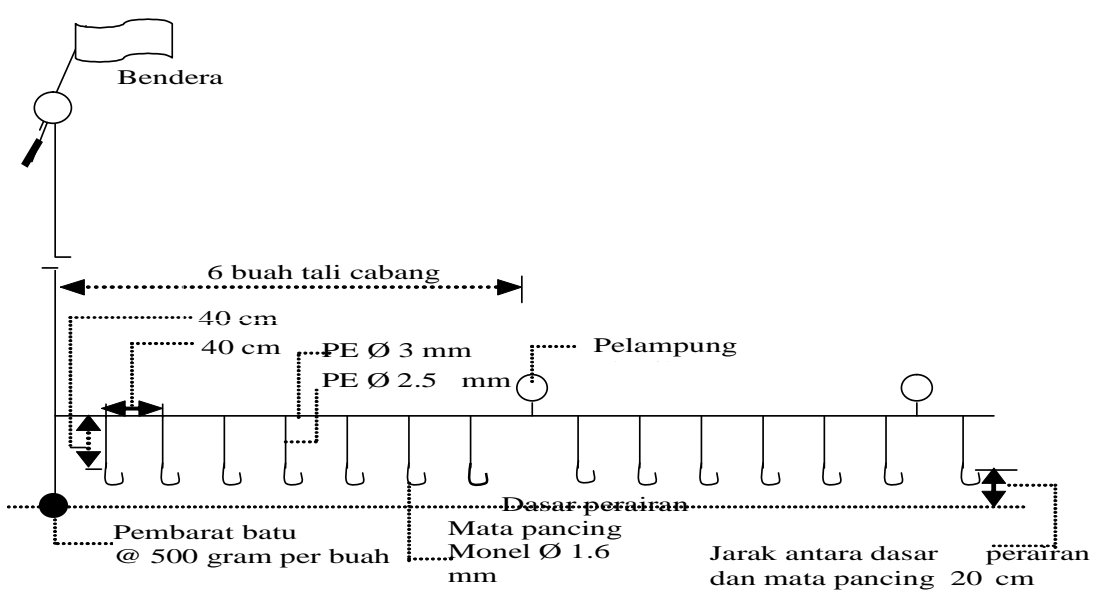

Gambar 4. Desain umum pancing senggol yang dioperasikan di Laut Jawa.

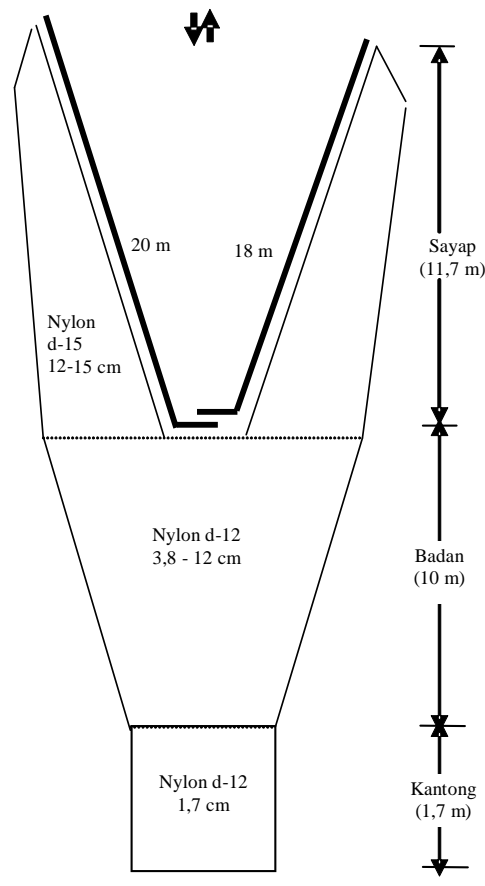

Gambar 5. Desain umum jaring dogol yang diopersikan di Laut Jawa.

Jaring dogol dioperasikan dengan kapal bermotor ukuran antara 10-30 GT dengan tenaga penggerak antara 30-100 HP. Armada jaring dogol yang menggunakan kapal kecil, sekitar $10 \mathrm{GT}$ ditemukan di Muara Anke (DKI Jakarta), Cirebon (Jawa Barat),
Pekalongan dan Juwana (Jawa Tengah). Sedangkan armada jaring dogol dengan kapal ukuran besar, sekitar 30 GT banyak ditemukan di Pelabuhan Juwana. Lama trip kapal jaring dogol ukuran kecil pada umumnya 1 hari per trip. Sedangkan armada jaring 
dogol dengan kapal besar pada umumnya 20 hari per trip. Kapal jaring dogol melakukan tawur jaring ratarata 8 kali per hari.

\section{b. Hasil Tangkapan}

\section{Jenis Ikan}

Pengamatan terhadap jenis-jenis ikan pari yang didaratkan di pusat-pusat pendaratan ikan di daerah penelitian menunjukkan bahwa paling tidak ada 36 jenis (species) ikan pari. Jenis ikan pari yang didaratkan di pusat-pusat pendaratan Muara Angke, Gebang, Pekalongan, dan Juwana secara gabungan disajikan pada Tabel 1. Tabel 1 terlihat bahwa ikan pari yang didaratkan tersebut didominansi oleh spesies-spesies sebagai berikut Himantura gerrardi $(30,07 \%)$, Dasyatis kuhlii (18,57\%), Himantura bleekeri (11,58\%), Aetoplatea zonura (6,28\%), dan Himantura jenkinsii (5,36\%).

Tabel 1. Spesies ikan pari di Laut Jawa yang berhasil diidentifikasi selama penelitian di pusat pusat pendaratan ikan di pantai utara Jawa

\begin{tabular}{|c|c|c|}
\hline No. & Spesies & $\%$ \\
\hline 1. & Himantura gerrardi (Gray, 1851) & 30,07 \\
\hline 2. & Dasyatis kuhlii (Muller \& Henle, 1841) & 18,57 \\
\hline 3. & Himantura bleekeri (Blyth, 1860) & 11,58 \\
\hline 4. & Aetoplatea zonura (Bleeker,1852) & 6,28 \\
\hline 5. & H. jenkinsii (Annandale, 1909) & 5,36 \\
\hline 6. & D. zugei (Muller \& Henle, 1841) & 4,59 \\
\hline 7. & H. undulata (Bleeker, 1852) & 3,59 \\
\hline 8. & H. uarnak (Forsskal, 1775) & 3,05 \\
\hline 9. & D. fluviorum (Ogilby, 1908) & 2,40 \\
\hline 10. & Rhynchobatus djiddensis & 2,11 \\
\hline 11. & H. imbricata (Bloch \& Schneider, 1801) & 1,51 \\
\hline 12. & H. walga (Muller \& Henle, 1841) & 1,37 \\
\hline 13. & H. fai (Jordan \& Seale, 1906) & 1,46 \\
\hline 14. & Aetobatus narinari (Euphrasen, 1790) & 1,26 \\
\hline 15. & Pastinachus sephen (Forsskal, 1775) & 1,17 \\
\hline 16. & Rhinobatos thouin (Lacepede, 1798) & 1,08 \\
\hline 17. & Aetomylaeus nichoffi (Bloch \& Scheider, 1801) & 0,86 \\
\hline 18. & D. thetidis & 0,68 \\
\hline 19. & H. chaopraya (Monkolprsit \& Roberts, 1990) & 0,66 \\
\hline 20. & Taeniura meyeni (Muller \& Henle, 1841) & 0,49 \\
\hline 21. & Rhynchobatus sp.1 & 0,26 \\
\hline 22. & D. microps (Annandale, 1908) & 0,23 \\
\hline 23. & Rhinoptera javanica (Muller \& Henle, 1841) & 0,20 \\
\hline 24. & Urogymnus asperrimus (Bloch \& Schneider, 1801) & 0,17 \\
\hline 25. & Rhina ancylostoma & 0,14 \\
\hline 26. & Aetobatus guttatus (Shaw, 1804) & 0,11 \\
\hline 27. & Aetomylaeus maculates (Gray, 1832) & 0,11 \\
\hline 28. & Himantura sp. (Last \& Stevens, 1994) & 0,11 \\
\hline 29. & Rhinobatos granulatus (Cuvier, 1829) & 0,11 \\
\hline 30. & H. granulata (Macleay, 1883) & 0,09 \\
\hline 31. & Mobula thusrtoni (Lloyd, 1908) & 0,06 \\
\hline 32. & Rhynchobatus sp.2 & 0,06 \\
\hline 33. & Aetomylaeus milvus (Muller \& Henle, 1841) & 0,03 \\
\hline 34. & Dasyatis akajei (Muller \& Henle, 1841) & 0,03 \\
\hline 35. & Gymnura japonica (Schlegal, 1850) & 0,03 \\
\hline 36. & G. poecilura (Shaw, 1804) & 0,03 \\
\hline
\end{tabular}

Sumber: Hasil penelitian 2005-2006

\section{Ukuran Ikan Pari}

Ukuran lebar disc (DW) ikan pari yang dominan tertangkap di perairan Laut Jawa yang didaratkan pusat-pusat pendaratan ikan di lokasi pengambilan sampel umum tanpa dipisahkan berdasarkan alat tangkapnya disajikan pada Tabel 2. Ikan pari jenis
Himantura gerrardi tertangkap di Laut Jawa pada kisaran ukuran lebar disc $11-120 \mathrm{~cm}$ dengan rata-rata ukuran disc ikan pertama kali dewasa $\left(\mathrm{DW}_{\mathrm{m}}\right.$ ) berdiameter $45 \mathrm{~cm}$. Ikan pari jenis Dasyatis kuhlii tertangkap pada kisaran ukuran DW $10-40 \mathrm{~cm}$ dengan rata-rata $\mathrm{DW}_{\mathrm{m}} 24 \mathrm{~cm}$. Ikan pari jenis Himantura bleekeri tertangkap pada kisaran ukuran DW 27-126 
cm dengan rata-rata $\mathrm{DW}_{\mathrm{m}} 58 \mathrm{~cm}$. Ikan pari jenis Aetoplatea zonura tertangkap pada kisaran ukuran DW 28-156 cm dengan rata-rata $\mathrm{DW}_{\mathrm{m}} 53 \mathrm{~cm}$. Ikan pari jenis Himantura jenkinsii tertangkap pada kisaran ukuran DW 33-199 cm dengan rata-rata $\mathrm{DW}_{\mathrm{m}} 76 \mathrm{~cm}$. Sebaran ukuran cawan (DW) ikan pari sebagaimana disebutkan pada Tabel 2 disajikan pada Gambar 6 .
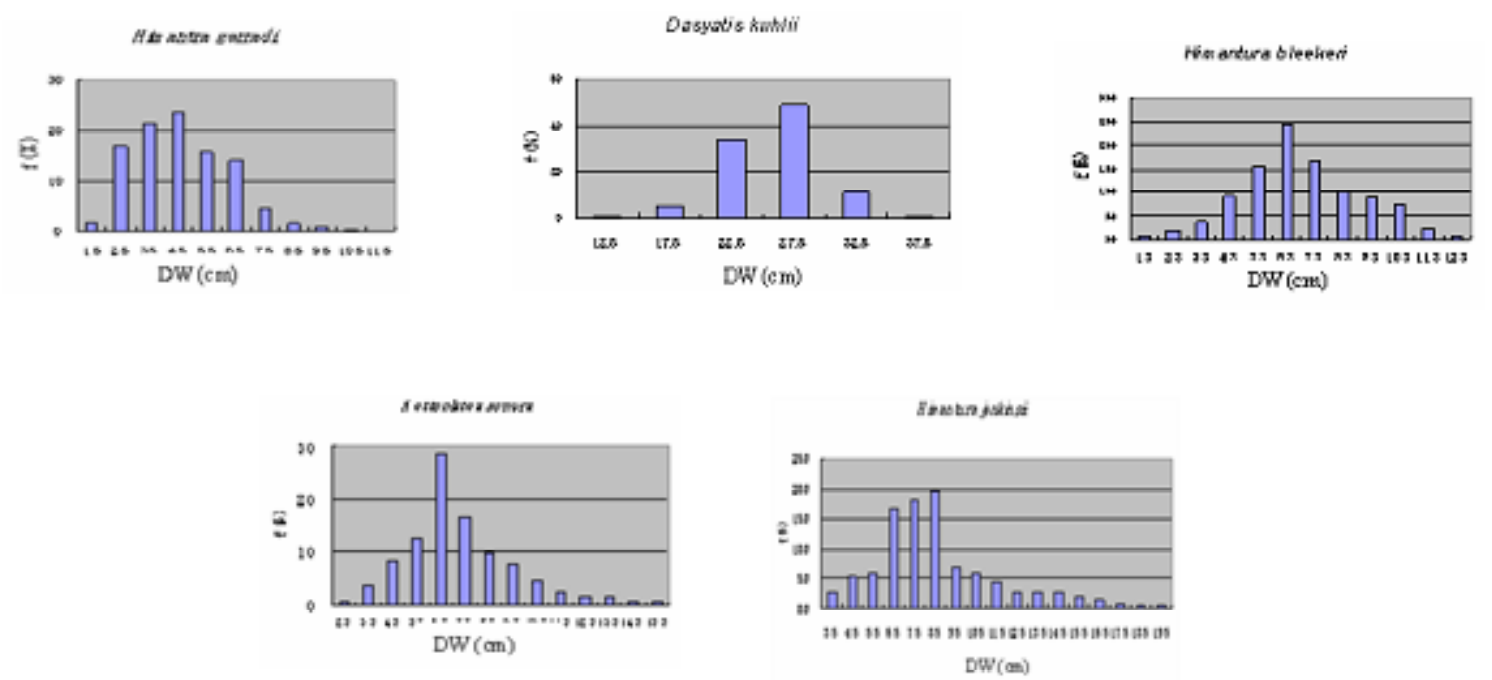

Gambar 6. Sebaran ukuran lebar cawan DW Himantura gerradi, Dasyatis kuhlii, Himantura bleekeri, Aetoplatea zonura, dan Himantura jenkinsi yang tertangkap di Laut Jawa.

Tabel 2.

Kisaran ukuran lebar disc DW ikan pari dan rataan lebar ikan pertama kali dewasa $\left(\mathrm{DW}_{\mathrm{m}}\right)$ beberapa jenis ikan pari yang dominan yang tertangkap di Laut Jawa

\begin{tabular}{|c|c|c|c|c|c|}
\hline \multirow{2}{*}{ No. } & \multirow{2}{*}{ Spesies } & \multicolumn{2}{|c|}{ DW (CM) } & \multirow{2}{*}{$\begin{array}{l}\text { Rata-rata DW } \\
\text { (CM) }\end{array}$} & \multirow{2}{*}{$\begin{array}{c}n \\
\text { (ekor) }\end{array}$} \\
\hline & & Minimum & Maksimum & & \\
\hline 1. & Himantura gerrardi & 11 & 120 & 45 & 1.524 \\
\hline 2. & Dasyatis kuhlii & 10 & 40 & 24 & 919 \\
\hline 3. & Himantura bleekeri & 27 & 126 & 58 & 715 \\
\hline 4. & Aetoplatea zonura & 28 & 156 & 53 & 595 \\
\hline 5. & Himantura jenkinsii & 33 & 199 & 76 & 404 \\
\hline
\end{tabular}

Keterangan: DW: lebar disc ikan pari, $\mathrm{DW}_{\mathrm{m}}$ : ukuran rata-rata lebar disc ikan pari pertama kali dewasa; $\mathrm{n}$ : jumlah contoh

\section{Selektivitas}

Salah satu sifat alat tangkap ikan pari yang selektif mempunyai kemampuan tangkap di mana ikan pari yang tertangkap mempunyai ukuran $\mathrm{DW}_{\mathrm{c}}>\mathrm{DW}_{\mathrm{m}}$. $\mathrm{DW}_{\mathrm{c}}$ adalah ukuran ikan pari yang pertama tertangkap oleh sebuah alat tangkap. $\mathrm{DW}_{\mathrm{m}}$ adalah ukuran ikan pari yang pertama matang gonad. Dengan demikian ikanikan pari yang tertangkap pada umumnya adalah ikan pari dewasa yang telah atau pernah beranak minimal 1 kali. Keadaan demikian akan mempertahankan sumber daya ikan pari dapat terjaga kelestariannya. Guna melihat performasi selektivitas beberapa alat tangkap ikan terhadap ikan pari dominan di perairan Laut Jawa, maka telah dianalisis 3 alat tangkap yaitu jaring dogol, jaring liongbun, dan pancing senggol, dan hasil analisisnya disajikan pada Gambar 6 .
Dari Gambar 7 dapat dijelaskan bahwa jaring dogol pada umumnya menangkap ikan pari jenis yang dominan (Himantura gerrardi, Dasyatis kuhlii, dan Himantura bleekeri) $>50 \%$ berukuran lebih kecil dari ukuran ikan mulai dewasa $\left(\mathrm{DW}_{\mathrm{m}}\right)$. Adapun alat tangkap jaring liongbun dan pancing senggol menangkap ikan pari jenis dominan (Himantura gerrardidan Dasyatis kuhlii) antara $17-25 \%$ berukuran $<\mathrm{DW}_{\mathrm{m}}$ dan Himantura bleekeri $>50 \%$ berukuran $<\mathrm{DW}_{\mathrm{m}}^{\mathrm{m}}$. Karena jaring dogol menangkap ikan lebih dari $50 \%$ berupa ikan pari berukuran $<\mathrm{DW}_{\mathrm{m}}$, maka dapat dikatakan bahwa jaring dogol tergolong alat tangkap yang tidak selektif menangkap ikan pari. Sedangkan jaring liongbun dan pancing senggol menangkap ikan pari kurang dari $50 \%$ berukuran $<\mathrm{DW}_{\mathrm{m}}$, maka dapat dikatakan bahwa jaring liongbun dan pancing senggol tergolong alat tangkap selektif bagi ikan pari. 

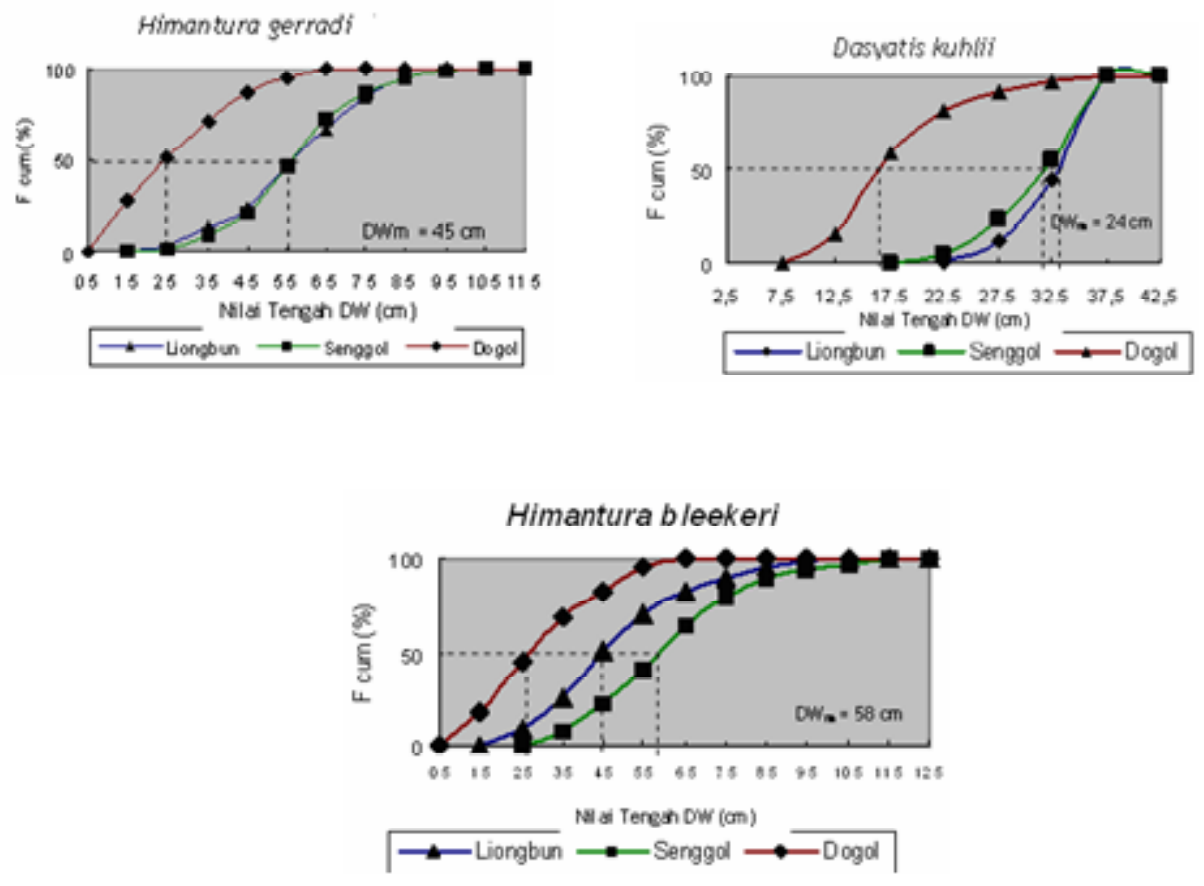

Gambar 7. Selektivitas alat tangkap jaring dogol, jaring liongbun, dan pancing senggol terhadap ukuran ikan pari jenis Himantura gerrardi, Dasyatis kuhlii, dan Himantura.bleekri.

\section{KESIMPULAN}

1. Dari 3 alat tangkap ikan pari (jaring dogol, jaring liongbun, dan pancing senggol) yang diriset, menunjukkan bahwa jaring liongbun dan pancing senggol merupakan alat tangkap yang bersifat selektif untuk menangkap ikan pari di Laut Jawa.

2. Jaring lionbun dan pancing senggol dapat dipilih dalam rangka pengembangan teknologi alat tangkap ikan pari di Laut Jawa.

\section{PERSANTUNAN}

Kegiatan dari hasil riset perikanan Elasmobranchii di Laut Jawa, T. A. 2005-2006, di Balai Riset Perikanan Laut-Muara Baru, Jakarta.

\section{DAFTAR PUSTAKA}

Compagno, L. J. V. 1999. The Living Marine Resource of the Western Central Pacific Vol.3 FAO. Rome. 1.398-1.529.

Durand, J. R. \& D. Petit. 1997. The Java Sea Environtment. BIODINEX. Java Sea Pelagic Fishery Assessment Project. 15-38.

Isa, M. M., H. Kohno, Hi. Ida, H. T. Nakamura, A. Zaenal, \& S. A. S. A. Kadir. 1998. Field Guide to Impotrant Commercial Marine Fishes of the South China Sea. SEAFDEC. Malaysia. 285 pp.

Tarp, T. G. \& P. J. Kailola. 1982. Trawled Fishes of Southern Indonesia and North-Western Australia. ADAB, GDF, and GTZ. Singapore. 406 pp. 